\title{
THE INHERITANCE OF B CHROMOSOMES \\ IN ZEA MAYS
}

\author{
MARGARET BLACKWOOD \\ Botany School, University of Melbourne
}

I. INTRODUCTION

Received $16 . i .56$

Some stocks of maize carry supernumerary or B chromosomes, whose morphology and mode of inheritance differ from that of the normal or A chromosomes. The B chromosomes tend to be unequally distributed to the gametes, so that progeny plants appear with numbers of $\mathrm{B}$ chromosomes both larger and smaller than the mean number present in the parents. The mean number and the distribution of B chromosomes to the progeny is different according to whether they are contributed through male or female gametes. When the $\mathrm{B}$ chromosomes are carried by the male parent only, the number of plants with even numbers of $\mathbf{B}$ chromosomes (including zero as an even number) may exceed those with odd numbers.

There has been some suspicion that B chromosomes may be lost from a plant, or from some cells of it, so that there must be some compensatory mechanism to maintain the frequencies in the population. Darlington and Upcott (194I) considered that the B chromosomes confer a selective advantage upon the plants possessing them, to compensate for the mitotic losses which they observed. Randolph (1941) and Roman (1948) have suggested that the presence of B chromosomes is disadvantageous to the plants. They found nondisjunction of B's at the second pollen-grain division and preferential fertilisation of the egg by the gamete carrying the B's. These mechanisms together tend to ensure the retention and possible increase of $\mathrm{B}$ chromosomes in the population.

This investigation was undertaken to assess the effects of nondisjunction and preferential fertilisation upon the maintenance of B's in the population. Particular attention was devoted to the detection of genetic control of these behaviours.

\section{MATERIALS AND METHODS}

All the stocks used were provided by Dr D. G. Catcheside, then at Cambridge, who had received the foundation seed containing $B$ chromosomes from Dr Herschel Roman, University of Washington, Seattle, Washington, U.S.A. The B stocks were crossed to stocks from other sources.

All material was fixed in acetic-alcohol used as a I to 3 mixture. After two days' fixation it was stored in a refrigerator at about $4^{\circ} \mathrm{C}$. Squash preparations of roots and pollen mother cells were stained with iron-aceto-carmine and mounted in "Euparal".

The B chromosome numbers of plants used in crosses were determined in the root tips of seedlings and were later checked in pollen mother cells. The progeny $\mathrm{B}$ chromosome numbers were counted only in root tips. 
The work was carried out at the Botany School, Cambridge, and a field plot at the Rockefeller Experimental Station there was made available for planting during 1949 and 1950 .

\section{EXPERIMENTAL}

Non-disjunction of the B chromosomes was found to occur at anaphase I of meiosis and also at the second division of the pollen grain nucleus. Observations of the distributions of B's at various stages in the development of pollen mother cells and pollen grains and in the progeny of plants with known B numbers, were made in order to estimate the rates of non-disjunction and of preferential fertilisation.

These observations were made in plants with I, 2 and 3 B chromosomes and in the progeny from crosses of these plants with plants with no B chromosomes. All the B's observed in these stocks were of the standard type described by McClintock (1933), constant in size and appearance, club-shaped at metaphase of mitosis, about two-thirds of the length of the smallest A chromosome in maize, and characterised by the large amount of heterochromatin at the distal end.

\section{(i) Somatic aberrations}

There is no significant loss of the B's by fragmentation and irregular movement during mitosis in the root tip. Of 355 root tips examined, 3 only (less than I per cent.), showed different B chromosome numbers in cells of the same root, and then the major occurrence of variation was in one plant, suggesting some genetic control of this variation. The infrequent occurrence of such variation excluded it as an important factor in the inheritance of the B's. In 62 plants, whose roots and, later, pollen mother cells were examined, only two showed a change -i.e. in 3.2 per cent. of the plants. One showed a loss of one B and the other a gain of one B. Evidently, irregularities in B chromosome behaviour are infrequent in somatic cells so that there is little change in the number of B's between the embryo and the adult. Any irregularities seem to occur in the seedling stage rather than at later stages of development.

\section{(ii) Meiotic behaviour}

During meiosis the B's lag behind the A chromosomes on the spindle, but no loss of B's was observed as a result. However, precocious division of the lagging B's at anaphase $I$ was found in the pollen mother cells with $\mathrm{I}$ and $2 \mathrm{~B}$ chromosomes. When followed by regular division at anaphase II, this resulted in a doubling of the number of B's present in the tetrad cells.

In 25 per cent. of the cells showing lagging B's at anaphase I in the I B plant, the single B had divided into two (fig. I). From such a cell, assuming regular division at anaphase II, each tetrad cell 
B CHROMOSOMES IN ZEA MATS

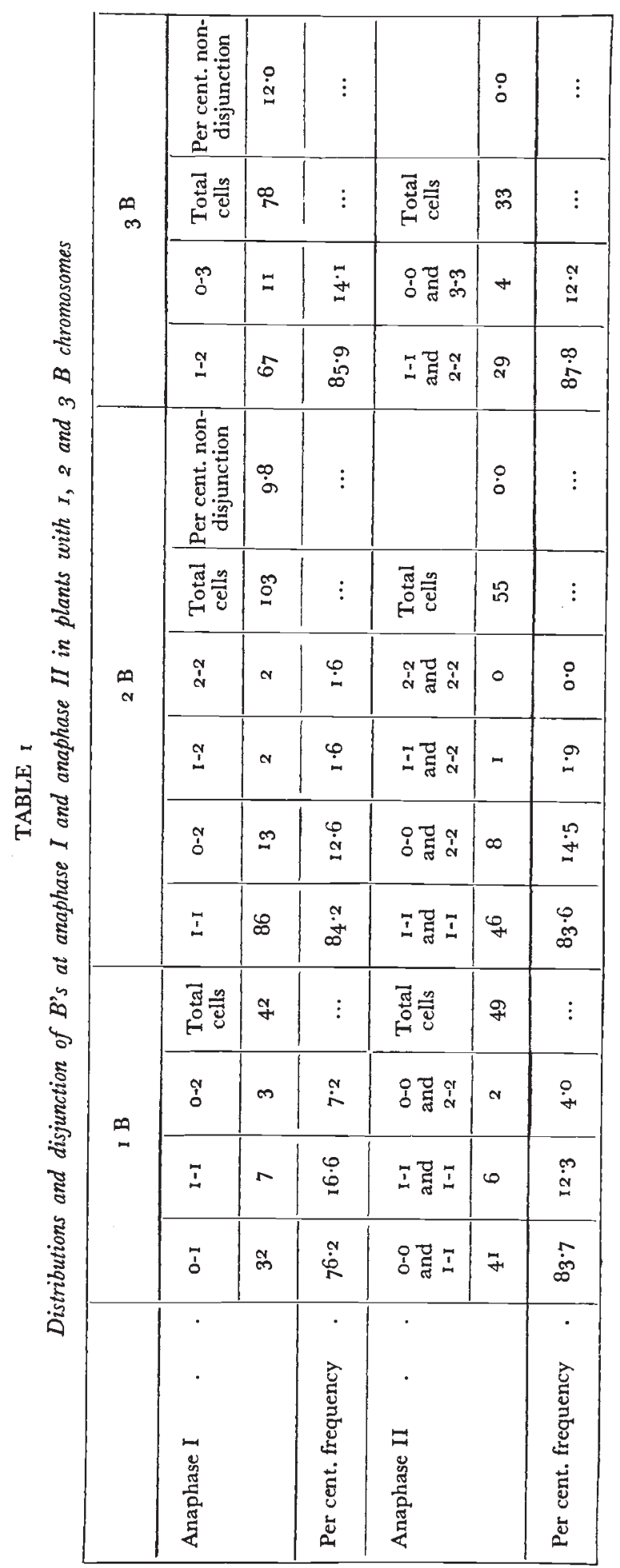


would contain one $B$ instead of half having one $B$ and half none. If the two products of this precocious division both moved to the one pole, tetrad cells could be produced with 2 B's in half of them and no B's in the other half (fig. 2). If, in addition, chromatid nondisjunction occurred at anaphase II, then it would be possible for one cell in some tetrads to have 4 B's. Three cells at anaphase I showed a $0-2$ distribution of the B's and two cells at anaphase II showed a 2-2 and o-o distribution (table $\mathrm{I}$ ). Both must have arisen from precocious division of the single $B$ at anaphase $I$.

Precocious division was observed in 3.2 per cent. of the cells examined with $2 \mathrm{~B}$ chromosomes. The two B's had each divided along the axis of the spindle while lying apart from and between the two groups of A chromosomes at mid-anaphase. They, presumably, would form four single B's and their distribution at random in the

TABLE 2

Associations of $B$ chromosomes during meiosis from pachytene to metaphase $I$ in plants with 1,2 and $3 B$ chromosomes

\begin{tabular}{|c|c|c|c|c|c|c|c|c|c|c|c|}
\hline & \multicolumn{3}{|c|}{ I B } & \multicolumn{3}{c|}{ 2 B } & \multicolumn{5}{c|}{3 B } \\
\cline { 2 - 9 } & Stage & with A & I & $\begin{array}{c}\text { Total } \\
\text { cells }\end{array}$ & 2 I & II & $\begin{array}{c}\text { Total } \\
\text { cells }\end{array}$ & 3 I & II and I & III & $\begin{array}{c}\text { Total } \\
\text { cells }\end{array}$ \\
\hline Pachytene & 3 & 84 & 87 & 0 & 30 & 30 & I & 50 & 22 & 73 \\
Diakinesis &. & $\ldots$ & 53 & 53 & 2 & 42 & 44 & 2 & 5 I & I5 & 68 \\
Metaphase I . & $\ldots$ & 40 & 40 & 4 & 66 & 70 & 3 & 48 & 20 & 7 I \\
\hline
\end{tabular}

Note.-At pachytene, I means a single B chromosome and II means an association of two B chromosomes which have synapsed, while III represents three B chromosomes which have synapsed together. At diakinesis and metaphase, I means a univalent, while II means a bivalent, and III represents a trivalent association held together by chiasmata.

telophase I groups would be $2-2, \mathrm{I}-3$ or $0-4$. If only one of the two B's divides precociously, then the possible distribution would be I-2 or $0-3$. In the cells observed at anaphase $I$ there were two with a distribution of I-2 and two with 2-2 (table I). These distributions could be the source of anaphase II cells with 2-2 and I-I or 2-2 and 2-2 distributions.

No pollen mother cells showing precocious division of B chromosomes were found in the $3 \mathrm{~B}$ plant (table $\mathrm{I}$ ), suggesting that such behaviour may be genetically controlled. Certainly, whether the $B$ number present is odd or even is not the controlling factor.

Non-disjunction at anaphase $\mathrm{I}$ in plants with $2 \mathrm{~B}$ and $3 \mathrm{~B}$ chromosomes is shown in table $\mathrm{I}$. In the true sense, non-disjunction implies the movement of the two or more homologous chromosomes to the same pole at anaphase I, i.e. chromosome non-disjunction. The term 
is also used to include chromatid non-disjunction, namely, the movement together to one pole of the two chromatids of each chromosome at anaphase of mitosis (Longley, I927, Randolph, I94I, Darlington and Upcott, I94I).

In the 2 B plant at anaphase I, distributions of B's observed were I-I, 0-2, I-2 and 2-2, the last two being the result of precocious division. The I-I would have come from normal disjunction of a B bivalent or from two univalents passing to opposite poles. The o-2 distribution would have come, presumably, from two univalents passing to one pole, but many more cells show this distribution than can be accounted for by such movement. At metaphase I only 5.6 per cent. of the pollen mother cells showed the $2 \mathrm{~B}$ chromosomes present as univalents (table 2). These would contribute equally to the $B$ distributions of $I-I$ and $0-2$, so that only 2.8 per cent. of $0-2$ would be expected as compared with the 12.6 per cent. observed. This difference, 9.8 per cent., is highly significant and may be attributed to chromosome non-disjunction of the B's in bivalents at anaphase I.

The $\mathrm{B}$ distributions at anaphase $\mathrm{I}$ in the $3 \mathrm{~B}$ plant provided evidence of the same kind of non-disjunction. Cells at anaphase I show $14 \cdot$ I per cent. of 0-3 distribution of which only about one-seventh can be accounted for by cells which had 3 univalents at metaphase $I$. Non-disjunction of bivalents and perhaps trivalents must therefore have occurred in at least 12 per cent. of all pollen mother cells.

Non-disjunction of the $B$ chromosomes at anaphase $I$ is one of the factors contributing to progeny with numbers of $\mathrm{B}$ chromosomes both larger and smaller than those expected from the numbers present in the parents.

No chromatid non-disjunctions of B chromosomes were seen at anaphase II, and there are no significant differences between the distribution frequencies at anaphase I and anaphase II in plants respectively with I, 2 and 3 B's (table I).

\section{(iii) Pollen grain division 1}

The first division of the pollen grain nucleus appears to be regular. No exceptional behaviour of the B's was noted, and chromatid nondisjunction at anaphase does not occur. The distributions of B's after the division (table 3) agree with the distributions observed at anaphase I and anaphase II, which have been calculated from the data recorded in table $I$.

(iv) B chromosome numbers in generative nuclei of pollen grains

In plants with $2 \mathrm{~B}$ chromosomes, the proportions of daughter cells with $\mathrm{O}, \mathrm{I}$ and $2 \mathrm{~B}$ chromosomes are similar at the end of the meiotic divisions and after the first division in the pollen grain. Hence the observations made at these stages may be combined to give estimates 


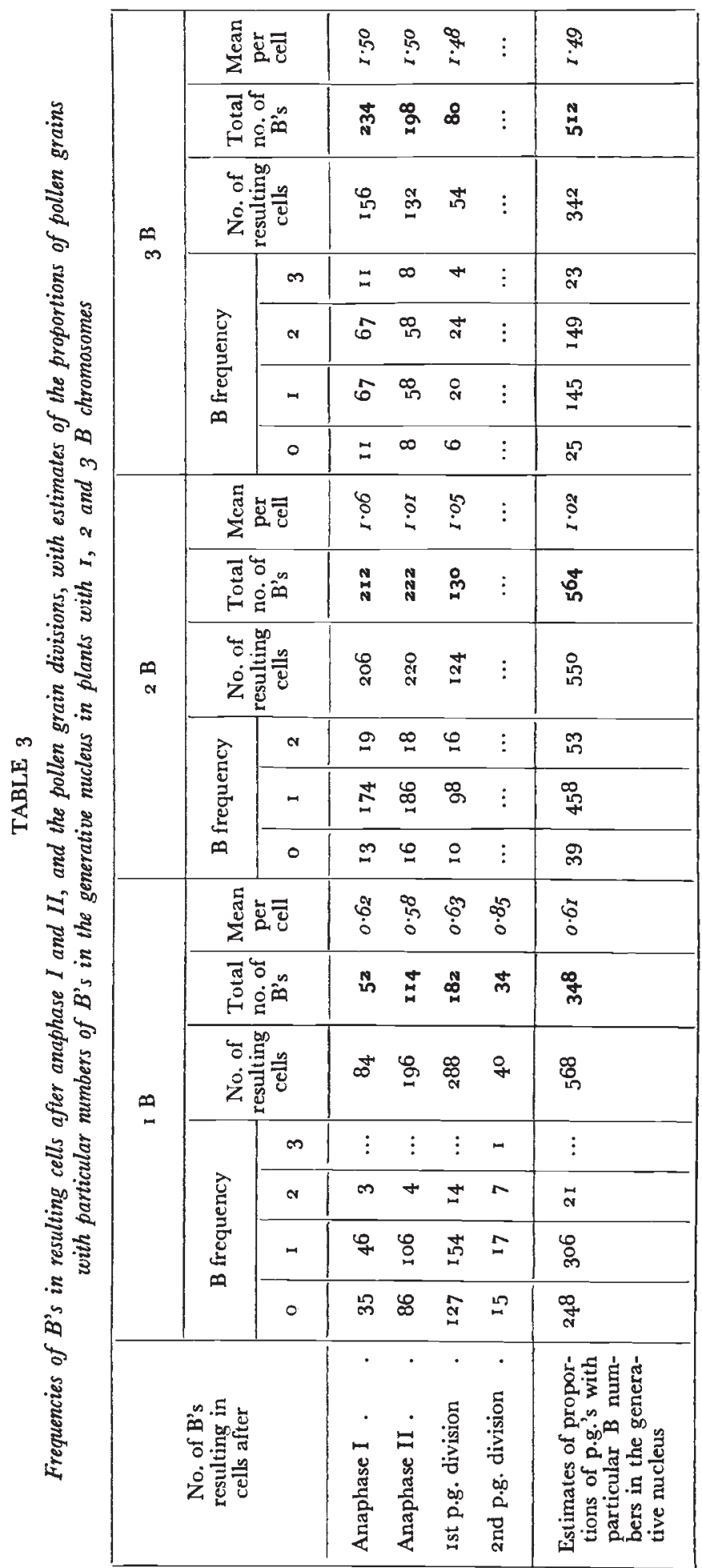


(table 3 ) of the proportions of pollen grains with o, I and $2 \mathrm{~B}$ chromosomes in the generative nucleus. Similar agreement between the proportions at the different stages are shown by plants with I and $3 \mathrm{~B}$ chromosomes and may be used to provide estimates of B distributions in the immature pollen grains in these plants.

\section{(v) Pollen grain division II}

The second division of the pollen grain nucleus was observed only in pollen grains from the I B plant and then with extreme difficulty. To see the chromosome behaviour during this division, the cytoplasm must be extruded from the pollen grain wall and the abundant starch grains removed. As a result, the number of cells showing anaphase stages in which the chromosomes may be counted is remarkably few. The chromosomes at this stage are very small, and close together.

Evidence of chromatid non-disjunction was found amongst 20

TABLE 4

Distribution of $B$ chromosomes at the anaphase stages of the first and second divisions of the pollen grain nucleus in a plant, No. ${ }_{152}$, with 1 B chromosome

\begin{tabular}{|c|c|c|c|c|c|c|c|}
\hline B distribution & $0-0$ & $\mathrm{I}-\mathrm{I}$ & $2-2$ & $0-2$ & $\mathrm{I}-3$ & $\begin{array}{c}\text { No. of } \\
\text { cells }\end{array}$ & $\begin{array}{c}\text { Per cent. } \\
\text { non- } \\
\text { disjunction }\end{array}$ \\
\hline $\begin{array}{c}\text { B frequencies at Ist anaphase } \\
\begin{array}{c}\text { B frequencies at 2nd anaphase } \\
\text { at division of generative } \\
\text { nucleus }\end{array}\end{array}$ & 50 & 77 & 7 & $\ldots$ & $\ldots$ & 144 & 0.0 \\
\hline
\end{tabular}

anaphase stages in which the B numbers in the two groups of chromosomes could be counted. If the second division were regular, the only distributions expected at anaphase would be o-o, I-I and 2-2. Five cells showed a $0-2$ and one showed a $1-3$ distribution (table 4). These two types could have appeared only as a result of chromatid non-disjunction, the first from division of a I B generative nucleus in which the two chromatids moved to the same pole, and the second from a generative nucleus with two B's, in which the chromatids of one B did not disjoin but moved together to one pole with one chromatid from the other $B$ which divided regularly. Thus 6 B's out of 17 observed at the second division of the pollen grain nucleus showed chromatid non-disjunction. The rate of non-disjunction is 35.3 per cent., but the observations are consistent at the 5 per cent. probability level with rates between 14 and 62 per cent. The range of $B$ numbers which can be transmitted to the progeny is thereby increased.

The apparent increase in the mean $(0.85$ as compared with $0.6 \mathrm{r})$ 
at the second pollen grain division is probably due to some selection of the cells actually recorded, those with no B chromosomes tending to be omitted unless they are particularly clear.

\section{(vi) B chromosome distributions in the progeny}

The numbers of $\mathrm{B}$ chromosomes in progeny of crosses between plants with and without B chromosomes are both greater and smaller than those in the parents (table 5). The mean is higher and there is a greater range in the numbers of B's in progeny where they were inherited from the male parent than in the reciprocals. In crosses where the $\mathrm{B}$ chromosomes were carried only by the male parent a larger number of progeny plants have even numbers of B chromosomes

TABLE 5

Frequency distribution of progeny plants with different $B$ chromosome numbers from reciprocal crosses between plants with and without $B$ chromosomes

\begin{tabular}{|c|c|c|c|c|c|c|c|c|c|c|c|c|c|c|c|}
\hline \multirow{2}{*}{$\begin{array}{l}\text { Parent } \\
\text { B no. }\end{array}$} & \multicolumn{8}{|c|}{ B frequency } & \multirow{2}{*}{$\begin{array}{l}\text { No. of } \\
\text { plants }\end{array}$} & \multirow{2}{*}{$\begin{array}{l}\text { No. of } \\
\text { B's }\end{array}$} & \multirow{2}{*}{$\begin{array}{l}\text { Per } \\
\text { cent. } \\
\text { gain }\end{array}$} & \multirow{2}{*}{$\begin{array}{l}\text { Per } \\
\text { cent. } \\
\text { loss }\end{array}$} & \multirow{2}{*}{ Mean } & \multirow{2}{*}{$\begin{array}{l}\text { Variance } \\
\text { of mean }\end{array}$} & \multirow{2}{*}{$\begin{array}{l}\text { Standard } \\
\text { error of } \\
\text { mean }\end{array}$} \\
\hline & 0 & I & 2 & 3 & 4 & 5 & 6 & 7 & & & & & & & \\
\hline $1 \times 0$ & I 2 & 16 & $\ldots$ & $\ldots$ & $\ldots$ & $\ldots$ & $\ldots$ & $\ldots$ & 28 & 16 & $14 \cdot 2$ & $\ldots$ & 0.57 & $0.009 \mathrm{I}$ & 0.095 \\
\hline $2 \times 0$ & 2 & $3^{I}$ & 3 & $\ldots$ & $\ldots$ & $\ldots$ & $\cdots$ & $\ldots$ & 36 & 37 & $2 \cdot 0$ & & I.03 & 0.0039 & 0.063 \\
\hline $3 \times 0$ & 2 & 14 & 12 & I & $\cdots$ & $\cdots$ & $\ldots$ & $\cdots$ & 29 & $4^{I}$ & $\ldots$ & $6 \cdot 0$ & $\mathrm{I} \cdot 4 \mathrm{I}$ & $0.016 \mathrm{I}$ & 0.127 \\
\hline $4 \times 0$ & $\ldots$ & 4 & 22 & 2 & $\ldots$ & $\cdots$ & $\cdots$ & $\cdots$ & 18 & 34 & $\ldots$ & $5 \cdot 5$ & $\mathrm{I} \cdot 8$ & 0.0178 & 0.133 \\
\hline $5 \times 0$ & $\ldots$ & $\ldots$ & 5 & 13 & 7 & $\ldots$ & $\ldots$ & $\ldots$ & 25 & 77 & $22 \cdot 8$ & & $3 \cdot 08$ & o.orgo & 0.138 \\
\hline $8 \times 0$ & $\ldots$ & $\ldots$ & 2 & 7 & 16 & 5 & I & $\ldots$ & 30 & 120 & $\ldots$ & $\ldots$ & 4.00 & 0.0089 & 0.094 \\
\hline $9 \times 0$ & $\ldots$ & ... & ... & 3 & 12 & II & I & I & 28 & 125 & $\ldots$ & $I \cdot 7$ & $4 \cdot 46$ & $0 \cdot 0268$ & $0 \cdot 164$ \\
\hline $0 \times I$ & 24 & 36 & 4 & I & ... & $\ldots$ & $\cdots$ & $\ldots$ & 65 & 47 & $37 \cdot 5$ & $\ldots$ & $0 \cdot 72$ & 0.0065 & $0 \cdot 08 \mathrm{I}$ \\
\hline $0 \times 2$ & 9 & 18 & 24 & 2 & 3 & $\ldots$ & $\cdots$ & $\ldots$ & $5^{6}$ & 84 & $50^{\circ} \cdot 0$ & $\ldots$ & 1.50 & 0.0175 & \\
\hline $0 \times 3$ & I 5 & 4 & 21 & 3 & 8 & I & $\ldots$ & $\ldots$ & 52 & $9^{2}$ & 18.0 & $\ldots$ & $1 \cdot 77$ & 0.0434 & 0.208 \\
\hline $0 \times 4$ & 5 & 2 & 10 & 3 & 7 & I & $\ldots$ & $\ldots$ & 28 & 64 & $14^{\circ} \mathrm{O}$ & $\ldots$ & $2 \cdot 28$ & 0.0244 & $0 \cdot 15^{6}$ \\
\hline
\end{tabular}

than odd numbers of B's, especially as the number of B's used in the cross increases. Finally, when the B number used in the cross is odd, there is a greater variance than when it is even, and as the B number increases there is an increase in the variance of the means when the odd and even numbered crosses are considered separately.

The first and second properties were observed by Longley (I927) for reciprocal crosses between plants with no B and I B chromosomes (table 6). Randolph (I94I) observed the first three properties for many different reciprocal crosses between plants with and without B's and between plants in which both parents carried B's. His data also show clearly the increase in the variance with increase in the parental numbers of B's.

Comparisons of the distributions of B's in the progeny of crosses involving similar numbers of B's show significant differences between 
the means in some cases, and in others, between the frequency distributions of B's. First, the progeny from reciprocal crosses between plants with no B's and plants with B's are statistically different. The means of Longley's two sets of frequencies in table 6 are not significantly different, but the distributions are $\left(\chi_{2}^{2}=19 \cdot 4\right)$. Randolph's data in the same table show a significant difference between the means. Similarly, the means of reciprocal crosses between o and 2 B plants are significantly different, both for Randolph's crosses (I94I) and those given in table 5. Next it was found that means of B frequency distributions in progenies from similar crosses of different origin could differ significantly. In the $I \times O$ and $O \times I$ crosses shown in table 6 , the means of $\mathrm{B}$ and $\mathrm{L}$ are significantly different, as are also the means of $B_{1}$ and $\mathrm{L}_{1}$.

These results suggested that the distribution of the B's to the

TABLE 6

The present, Longley's and Randolph's data, arranged for comparison, of frequency distributions of plants with different numbers of $B$ chromosomes in the progenies from reciprocal crosses between plants with $O B$ and plants with $I B$ chromosomes

\begin{tabular}{|c|c|c|c|c|c|c|c|c|c|}
\hline \multirow{2}{*}{$1 \times 0$} & \multicolumn{4}{|c|}{ B frequency } & \multirow{2}{*}{$\begin{array}{l}\text { No. of } \\
\text { plants }\end{array}$} & \multirow{2}{*}{$\begin{array}{c}\text { No. of } \\
\text { B's }\end{array}$} & \multirow{2}{*}{ Mean } & \multirow{2}{*}{$\begin{array}{l}\text { Variance } \\
\text { of mean }\end{array}$} & \multirow{2}{*}{$\begin{array}{l}\text { Standard } \\
\text { error of } \\
\text { mean }\end{array}$} \\
\hline & 0 & I & 2 & 3 & & & & & \\
\hline $\begin{array}{l}\text { B. } \\
\text { L. } \\
\text { R. }\end{array}$ & $\begin{array}{r}12 \\
109 \\
46\end{array}$ & $\begin{array}{l}16 \\
58 \\
19\end{array}$ & $\begin{array}{c}\ldots \\
3 \\
\cdots\end{array}$ & $\begin{array}{l}\cdots \\
\cdots \\
\cdots\end{array}$ & $\begin{array}{r}28 \\
170 \\
65\end{array}$ & $\begin{array}{l}16 \\
64 \\
19\end{array}$ & $\begin{array}{l}0.57 \\
0.38 \\
0.29\end{array}$ & $\begin{array}{l}0.0091 \\
0 \cdot 0016 \\
0 \cdot 0032\end{array}$ & $\begin{array}{l}0.095 \\
0.040 \\
0.057\end{array}$ \\
\hline $0 \times 1$ & & & & & & & & & \\
\hline $\begin{array}{l}\mathrm{B}_{1} \\
\mathrm{~L}_{1} \\
\mathrm{R}_{1}\end{array}$ & $\begin{array}{l}24 \\
76 \\
3^{2}\end{array}$ & $\begin{array}{l}36 \\
22 \\
13\end{array}$ & $\begin{array}{r}4 \\
15 \\
5\end{array}$ & $\begin{array}{c}1 \\
\cdots \\
2\end{array}$ & $\begin{array}{r}65 \\
113 \\
52\end{array}$ & $\begin{array}{l}47 \\
52 \\
29\end{array}$ & $\begin{array}{l}0.72 \\
0.46 \\
0.56\end{array}$ & $\begin{array}{l}0.0065 \\
0 \cdot 0046 \\
0 \cdot 013^{1}\end{array}$ & $\begin{array}{l}0.081 \\
0.068 \\
0.114\end{array}$ \\
\hline
\end{tabular}

gametes, particularly to the male gametes, might be under genetic control. Crosses were made between seed parents with no B's and pollen parents with two B's, to answer particular problems :-

(I) Four unrelated plants known to have no B's were pollinated by a single plant with 2 B's (table 7 , i-iv) to determine whether the genotype of the female parent would affect the range, frequencies, and distributions of the B's in the progeny ; and

(2) plants with no B chromosomes were pollinated by plants unrelated to one another and each with two B's (table 7 , $\mathrm{v}$-viii), to determine whether different male genotypes would give different ranges, frequencies and distributions of B's in the progeny. 
The first four samples in table 7 do not differ significantly from one another, either in their means or frequencies of plants with different $B$ numbers. Hence the female parent has no effect upon preferential fertilisation which, therefore, appears to be pre-determined by the pollen parent. These four progenies may be pooled to represent the performance of plant $\mathrm{i} 36$.

However, $v$ differs significantly from i-iv combined, both in the mean number of B's in the progeny and in the frequencies of different numbers. This difference lies especially in the relatively greater number of plants with odd $B$ numbers in $v$ than in any of the other four families which all show a pattern of greater frequencies of plants

TABLE 7

Frequency distribution of progeny plants with different $B$ chromosome numbers from crosses between plants with o $B$ chromosomes as the seed parents, and plants with $2 B$ chromosomes as the pollen parents

\begin{tabular}{|c|c|c|c|c|c|c|c|c|c|c|c|}
\hline \multirow{2}{*}{ Cross } & \multirow{2}{*}{$\begin{array}{l}\text { Parent } \\
\text { B no. }\end{array}$} & \multicolumn{5}{|c|}{ B frequency } & \multirow{2}{*}{$\begin{array}{l}\text { No. of } \\
\text { plants }\end{array}$} & \multirow{2}{*}{$\begin{array}{c}\text { No. of } \\
\text { B's }\end{array}$} & \multirow{2}{*}{ Mean } & \multirow{2}{*}{$\begin{array}{l}\text { Variance } \\
\text { of mean }\end{array}$} & \multirow{2}{*}{$\begin{array}{l}\text { Standard } \\
\text { error of } \\
\text { mean }\end{array}$} \\
\hline & & o & 1 & 2 & 3 & 4 & & & & & \\
\hline $\begin{array}{l}\text { (i) } 10 \times 136 \\
\text { (ii) } 11 \times 136 \\
\text { (iii) } 13 \times 136 \\
\text { (iv) } 16 \times 136\end{array}$ & $\begin{array}{l}0 \times 2 \\
0 \times 2 \\
0 \times 2 \\
0 \times 2\end{array}$ & $\begin{array}{l}4 \\
4 \\
3 \\
5\end{array}$ & $\begin{array}{l}1 \\
3 \\
2 \\
2\end{array}$ & $\begin{array}{r}19 \\
12 \\
9 \\
10\end{array}$ & $\begin{array}{l}0 \\
\text { I } \\
0 \\
0\end{array}$ & $\begin{array}{l}5 \\
4 \\
4 \\
3\end{array}$ & $\begin{array}{l}29 \\
24 \\
18 \\
20\end{array}$ & $\begin{array}{l}59 \\
42 \\
3^{2} \\
34\end{array}$ & $\begin{array}{l}2 \cdot 03 \\
1 \cdot 92 \\
2 \cdot 00 \\
1 \cdot 70\end{array}$ & $\begin{array}{l}0.0455 \\
0.0649 \\
0.0980 \\
0.0847\end{array}$ & $\begin{array}{l}0.213 \\
0.255 \\
0.313 \\
0.291\end{array}$ \\
\hline Totals & & 16 & 8 & $5^{\circ}$ & I & 16 & $9 \mathrm{I}$ & 171 & $1 \cdot 92$ & 0.0167 & 0.214 \\
\hline $\begin{aligned} \text { (v) } & 71 / 24 \times 75 / 18 \\
\text { (vi) } & 21 \times 116 \\
\text { (vii) } & 19 \times 114 \\
\text { (viii) } & 25 \times 13^{8}\end{aligned}$ & $\begin{array}{l}0 \times 2 \\
0 \times 2 \\
0 \times 2 \\
0 \times 2\end{array}$ & $\begin{array}{l}9 \\
6 \\
4 \\
8\end{array}$ & $\begin{array}{r}18 \\
16 \\
5 \\
9\end{array}$ & $\begin{array}{r}24 \\
22 \\
8 \\
12\end{array}$ & $\begin{array}{l}2 \\
1 \\
0 \\
2\end{array}$ & $\begin{array}{l}3 \\
3 \\
2 \\
0\end{array}$ & $\begin{array}{l}56 \\
48 \\
20 \\
31\end{array}$ & $\begin{array}{l}84 \\
75 \\
29 \\
39\end{array}$ & $\begin{array}{l}I \cdot 50 \\
I \cdot 56 \\
I \cdot 45 \\
I \cdot 25\end{array}$ & $\begin{array}{l}0.0175 \\
0.0194 \\
0.0434 \\
0.0171\end{array}$ & $\begin{array}{l}0.132 \\
0.139 \\
0 \cdot 208 \\
0.131\end{array}$ \\
\hline Totals & & 27 & $4^{8}$ & 66 & 5 & 8 & ×55 & 227 & $1 \cdot 47$ & 0.0064 & $0 \cdot 154$ \\
\hline (ix) Randolph's & $0 \times 2$ & 22 & o & 37 & 0 & 2 & $6 r$ & 82 & $1 \cdot 34$ & 0.0191 & $0 \cdot 13^{8}$ \\
\hline
\end{tabular}

with even than with odd numbers of B's. However, this type of distribution is less exaggerated in i-iv than in Randolph's data (table 7, ix). The mean of ix differs significantly $(\mathrm{P}<\mathrm{O} \cdot 0 \mathrm{I})$ from that of $\mathrm{i}$-iv but not from the mean of $v$. The frequencies of plants with different numbers of $\mathrm{B}$ chromosomes are very different in ix and $\mathrm{v}$ since there are relatively more plants with even numbers in Randolph's progeny. Indeed, $\mathrm{v}$ and ix differ very significantly $\left(\chi^{2}{ }_{2}=24 \cdot 7\right)$ in the distribution of frequencies of plants with different $B$ numbers in the progeny.

The other progenies, vi, vii and viii resemble $\mathrm{v}$ more closely than i-iv or ix. There are, relatively, more plants with odd numbers of B's present and, in viii, with the absence of any $4 \mathrm{~B}$ plants, a more equal distribution of plants with $\mathrm{O}, \mathrm{I}$ and 2 B's and a low mean of 
I.25, there seemed to be a shift towards a population with few or even no B chromosomes, even though it still shows a 25 per cent. gain over the expectation of I B chromosome per plant. However, the means and frequency distributions of vi-viii do not differ significantly from $\mathrm{v}$ nor between one another. It was therefore concluded that $\mathrm{v}$-viii were sufficiently homogeneous to pool and compare with other data. Their mean does not differ from that of Randolph's family, but the frequency distributions are very different $\left(\chi^{2}{ }_{3}=\right.$ $30 \cdot 1281$ ). The two groups i-iv and v-viii have significantly different means and frequency distributions.

Not only are unexpected B numbers found in progeny of a particular pollen parent, but different mean numbers of B's and dissimilar distribution frequencies occur in the progeny from similar crosses. These variations are dependent upon events which occur with variable frequency, in the development of the pollen grains and the events leading to fertilisation in the embryo sac. However, the seed parent is without effect upon the behaviour of the male gametes.

\section{DISCUSSION}

In these stocks, mitotic lapses of the $\mathrm{B}$ chromosomes have been found to be infrequent and the amount of loss or gain of B's during meiosis due to lagging and precocious division does not affect, significantly, the conclusions to be drawn from progeny analysis. Randolph (I94I) considered such lapses to be insignificant in his material, yet Darlington and Upcott (I94I) observed them frequently enough to suggest that the B's confer a compensating selective advantage to the plant. All these observations indicate that the frequency and extent of such aberrations vary between stocks. However, the different rates of precocious division found in cells with I, 2 and 3 B chromosomes, namely 23,3 and o per cent. is a reflection of the different frequencies of univalents in such cells.

Non-disjunction of the $\mathrm{B}$ chromosomes in maize and other plants has been reported as occurring at various stages during meiosis and at both the pollen grain divisions. In maize, Longley ( 1927) observed it at anaphase II, while Randolph (I94I) and Roman (1947) both inferred from genetical results that it occurred at the second pollen grain division. In other plants, most cases of non-disjunction have been described as occurring at the first pollen grain division. Müntzing (1946) in Secale, Óstergren (1947) in Anthoxanthum and Bosemark (1950) in Festuca all observed it at this stage and, in the last two examples, only on the male side. Håkansson described non-disjunction in the embryo sac of Secale. In Secale, in the pollen grain, directed non-disjunction takes place, so that the larger number of B's pass into the generative nucleus, increasing the number of B's per gamete.

The general effect of non-disjunction is to alter the distribution of B's in resultant cells, but not the total nor the mean number per cell. Daughter cells may have either smaller or larger numbers than 
the parent and even rather than odd numbers of $\mathrm{B}$ chromosomes. The frequency of non-disjunction is reflected in the relative numbers of progeny with even and with odd numbers of B's, the rate of nondisjunction being inversely related to the proportion of plants with odd numbers.

In maize, non-disjunction occurs at two stages in the male parent during the reproductive phase. Chromosome non-disjunction occurs at anaphase $I$ and chromatid non-disjunction at the second pollen grain division. They account for the wider range in B frequencies in the progeny than could be obtained from a single occurrencee.g. from o-4 for a 2 B plant. At anaphase I, the rate of chromosome non-disjunction in the $2 \mathrm{~B}$ and $3 \mathrm{~B}$ cells was of the order of Io per cent. The rate of chromatid non-disjunction at the second pollen grain division, in the I B plant, was 35 per cent. Although similar observations were not made at pollen grain division II in plants with 2 and 3 B's, the progeny frequencies of B's indicated its occurrence at this stage. For instance, at the end of the first pollen grain division in the $2 \mathrm{~B}$ plant, the generative nucleus had either $\mathrm{O}$, I or $2 \mathrm{~B}$ chromosomes, but the progeny from the $0 \times 2$ cross included plants with o, I, 2, 3 and 4 B's. Plants with 3 and 4 B's must have originated from eggs fertilised by gametes with 3 and $4 \mathrm{~B}$ chromosomes, derived from non-disjunction of $2 \mathrm{~B}$ 's at the second pollen grain division. Distributions of B's in progeny from crosses in which only the seed parent carried the B's, indicate that non-disjunction takes place at some stage in the development of the egg. The B distributions in the progeny from the crosses $2 \mathrm{~B} \times 0$ and $3 \mathrm{~B} \times 0$ are not significantly different from those at the first pollen grain division in the $2 \mathrm{~B}$ and $3 \mathrm{~B}$ plant (respectively, $\chi^{2}{ }_{2}=0.3824$ and $\chi^{2}{ }_{3}=\mathrm{I} \cdot 495^{8}$ ). The observations agree with the assumption that only chromosome nondisjunction occurs on the female side, at a rate equal to that in pollen mother cells. There is no evidence of chromatid non-disjunction at post meiotic division in the embryo sac.

In the progenies from crosses in which different pollen plants with the same number of $B$ chromosomes were used as parents, the frequencies of the progeny plants with different $B$ numbers showed differences sometimes in their mean and distributions, sometimes in their distributions alone.

A significant difference between the means of such progeny could be due to different rates of non-disjunction at the second pollen grain division with a given rate of preferential fertilisation, or to different rates of preferential fertilisation following a given rate of non-disjunction or to variation of both. Likewise variation in either factor may alter the distribution. Consequently, more searching analysis is needed to determine which factor is responsible for a particular effect.

Non-disjunction at the second pollen grain division leads to a relative increase in the proportion of gametes with even (including 
zero) numbers of B's. The ratio of the number of progeny with even (including zero) to odd numbers of $\mathrm{B}$ chromosomes provides a measure of the rate of non-disjunction. The ratios are 0.9 for the first group (i-iv), 0.64 for the second group ( $\mathrm{V}$-viii) and $\mathrm{I} \cdot \mathrm{O}$ for Randolph's data.

It is clear that the rate of non-disjunction is inconstant for a particular chromosome number. It is not yet known whether the rate is constant for a particular plant throughout the period of pollen shedding. Also whether environment affects the rate is unknown. Certainly, different plants behave differently on the same day, but this could be a reflection either of different states of maturity or of innate genetic differences between plants.

Preferential fertilisation of eggs by male gametes with larger numbers of B's can only occur when non-disjunction at the second pollen grain division has taken place and will therefore lead, in the case of the $0 \times 2 \mathrm{~B}$ cross, to a deviation from equality of the number of progeny with even as compared with zero B's. The proportion of heterogametic pollen grains in which the male gamete with the larger number of B's preferentially fertilises the egg is approximately the ratio of their differences to their sum of the number of progeny with even and zero numbers of B's. The ratio has the values of $0.6 \mathrm{I}$, 0.47 and 0.28 respectively, for the three groups of data. It would seem that the frequency of preferential fertilisation may also be variable and, if so, genetically controlled. However, such variability is unproven.

More precise estimates of these two factors need a more sophisticated treatment (Catcheside, I956) because of the complex way in which the two interact.

If the presence of B's confers an advantage upon the plant, as Darlington and Upcott (I94I) suggested, then with the mechanisms of non-disjunction and preferential fertilisation together giving rise to progeny plants with larger $B$ numbers, an increase in the number of $B$ 's in the population during succeeding generations might be expected. There is no evidence for any such population gain. Rather it would seem that the presence of B's confers a selective disadvantage and that non-disjunction followed by preferential fertilisation ensures the retention of the B's in the population. It is not yet apparent what the disadvantage is, nor to what extent genetic control maintains the $\mathrm{B}$ chromosomes in the population.

\section{SUMMARY}

I. During mitosis irregularities in the behaviour of $\mathrm{B}$ chromosomes were infrequent. During meiosis, lagging and precocious division occurred with effects upon the distribution of B's to the progenies.

2. Chromosome non-disjunction of the $B$ chromosomes was observed at anaphase $\mathrm{I}$ of meiosis in pollen mother cells and chromatid nondisjunction at the second division of the pollen grain nucleus. 
3. Analysis of $\mathbf{B}$ chromosome distributions in the progeny showed that non-disjunction occurred at varying rates in different plants, even in unrelated ones with the same $\mathrm{B}$ number. This might be due (i) to differences in the A genotypes, the rate of non-disjunction and the stage at which it occurs being under genetic control, or (ii) to differences between the $\mathrm{B}$ chromosomes themselves.

4. The occurrence of preferential fertilisation was confirmed and, since this process, following upon non-disjunction, promotes the retention of $\mathrm{B}$ chromosomes in the population, and there is no population gain of B's, it is suggested that the $\mathrm{B}$ chromosomes confer a disadvantage upon the sporophyte.

Acknowledgments.-I wish to express my gratitude to Professor D. G. Catcheside, F.R.s., for his advice and helpful criticism and my thanks to Mr W. M. Harper, Defence Standard Laboratories, Melbourne, Australia, for assistance with statistical matters. I am also indebted to the Commonwealth Government of Australia for an ex-service scholarship enabling me to proceed overseas and carry out the work.

\section{REFERENCES}

bosemark, N. O. 1950. Accessory chromosomes in Festuca pratensis Huds. Hereditas, $36,366-368$.

CATCHeside, D. G. 1956. The genetics of B chromosomes in maize. Heredity, ro, 345-35I.

DARLINGTON, C. D., AND UPCOTT, M. 1941. The activity of inert chromosomes in Zea mays. F. Genet., 4I, 275-296.

HÅkANSSON, A. 1948. Behaviour of accessory rye chromosomes in the embryo-sac. Hereditas, 34, 35-59.

LONGley, A. E. 1927. Supernumerary chromosomes in Zea mays. F. Agric. Res., $35,769-784$.

MCCLINTOCK, B. 1933. The association of non-homologous parts of chromosomes in the mid-prophase of meiosis in Zea mays. Z. Zellf. Mik. Anat., 19, 191-237.

MüNTZING, A. 1946. Cytological studies of extra fragment chromosomes in rye. III. The mechanism of non-disjunction at the pollen mitosis. Hereditas, 32, 97-II 19 .

östergren, G. 1947. Heterochromatic B chromosomes in Anthoxanthum. Hereditas, $33,261-296$.

RANDOLPH, L. F. 1941. Genetic characteristics of the B chromosomes in maize. Genetics, 26, 608-631.

ROMAN, HERSGHEL. 1947. Mitotic non-disjunction in the cases of interchanges involving the B-type chromosome in maize. Genetics, 32, 391-409.

ROMAN, herschel. 1948. Directed fertilisation in maize. P.N.A.S., 34, 36-42. 